\title{
Religious Expression In The Growing Multicultural Workplace
}

\author{
Garry Rollins, (E-mail: grollins@belhaven.edu), Belhaven College
}

\begin{abstract}
The twentieth century saw incredible growth in the diversity of the American workplace as barriers, especially for women and minorities, were reduced. In this twenty-first century the effects of globalization are adding to the company's diversity. Today, some companies reflect a microcosm of our world as the world's workers come to America and technology connects organizations worldwide. With this diverse workplace come not only the obvious differences of gender, race, and national origin, but also differences in religion and religious practices. This research examines some trends in American workplace diversity, the historical and legal framework into which diverse religions can function in America, and corporate practices necessary to enable religious expression without significantly diminishing the organization's efficiency. The research concludes by reporting results of a survey on religious expression difficulties and solutions in the workplace.
\end{abstract}

\section{INTRODUCTION}

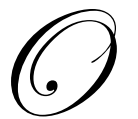

ne need only look at our schools and universities, our shopping centers and our business offices to realize the growing diversity in America. The question for many employers and their employees is: how could (or even should) diverse religious beliefs and practices impact the workplace? Here are a few examples cited by The Kansas City Star:

- A worker who is Jewish is assigned to work Saturdays. But that's the Sabbath in his faith. He asked for Saturdays off, agreeing to work Sundays instead.

- $\quad$ A Muslim worker needs a break each day to do a required Islamic prayer.

- A Christian worker plans to decorate her office space with a Christmas tree and Nativity scene. (Gray, 2002)

Cases reported in The Salt Lake Tribune have been:

- A Pentecostal Christian female at Brink's Inc. asks to let her provide a matching uniform skirt since her faith forbid women wearing pants.

- A federal postal employee was asked not to wear his T-shirt supporting his Wicca (witchcraft) faith because its images offended some female coworkers (Gellor, 2003).

Adam Gellor (2003) of The Salt Lake Tribune goes on to asks: "Do employers have to accommodate these employees' religious needs or wants? Do employees have the right to practice their faith in the workplace? Are their rights protected by law? The answer to all of the above is yes but not necessarily." Even listening to the experts leaves one confused. In their 1999 survey of religious bias in the workplace, the Tanenbaum Center for Interreligious Understanding (1999) stated that "Religious bias is a reality of the workplace and of strong concern to the workforce" Yet David Frank, a legal spokesperson for the Equal Employment Opportunity Commission, stated that only 2.5\% of cases in recent years' have involved religious discrimination claims (Pew Forum on Religion and Public Life, 2002). Is religious discrimination in the workplace a real problem and a valid concern? Also, what impact has the trend toward multiculturalism played in America's workplaces? One must first understand the changes in American workplaces to understand the religious diversity found there. 


\section{GROWING RELIGIOUS DIVERSITY IN THE WORKPLACE}

America has often been described as a melting pot of people from other countries; therefore, understanding our world's religious diversity is where to begin. Table 1, taken from Diversity Resources, Inc., lists the world population by its religious background for the year 2000 .

Table 1

Religious Adherents as a Percentage of World Population in 2000

\begin{tabular}{lc}
\hline Religion & $\%$ \\
Christians & $33.0 \%$ \\
Muslims & $19.6 \%$ \\
Hindus & $13.4 \%$ \\
Non-Religious & $12.7 \%$ \\
Chinese Folk & $6.4 \%$ \\
Buddhists & $5.9 \%$ \\
Ethno Religionists & $3.8 \%$ \\
Atheists & $2.5 \%$ \\
New Religionists & $1.7 \%$ \\
Sikhs & $.4 \%$ \\
Jews & $.2 \%$ \\
Others & $.4 \%$ \\
\hline
\end{tabular}

Source: Richard T. Alpert, President; Diversity Resources, Inc.

This diverse religious population is encountered two ways. First, American companies are seeking worldwide customers. With $95 \%$ of the world's customers living outside of the United States (Sampson, 2004), American companies are increasingly engaging foreigners as both clients and employees of overseas subsidiaries. Second, many of the world's workers are migrating to America as they seek economic opportunities. Either way, American employers and employees are encountering people of other religions in their workplaces. In a 2001 survey of human resource management professionals, $36 \%$ of the respondents recognized an increase in religions represented in their workplaces in the past five years (Tanenbaum Center for Interreligious Understanding, 2001). This growing religious diversity brings with it changes in dress, appearance, holiday requests, breaks for prayer times, and a host of other issues.

Where companies are used to accommodating only traditional Christian workers' requests, new challenges exist. In fact the American Religious Identification Survey 2001 (ARIS) noted the portion of the American adult population classifying itself as Christian declined from 86\% to 77\% between 1990 and 2001 (Kosmin, Mayer \& Keysan, 2001). In Table 2, taken from Exhibit 1 of the ARIS survey, one can see the growth in other religions in America between those dates. The ARIS survey concluded that overall growth in those claiming religions other than Christian rose only from 3.3\% to 3.7\% (Kosmin, Mayer, \& Keysan, 2001). One must consider, however, that among the top five groups in Table 2, all surpass several of the many Christian denominations in size. Employers recruiting younger workers are even more likely to encounter growing religious diversity since some religions such as the Muslims and Buddhists have over 55\% of their followers between ages 18-29 in America (Kosmin, Mayer \& Keysan, 2001, Exhibit 11).

Not only are workers becoming more religiously diverse, they are also reluctant to "check their religion" at the company door. 
Table 2

Change in Non-Christian Religions between 1990 and 2001

\begin{tabular}{lrr}
\hline Religion Groups & $\mathbf{1 9 9 0}$ & $\mathbf{2 0 0 1}$ \\
Jewish & $3,137,000$ & $2,831,000$ \\
Muslim/Islamic & 527,000 & $1,104,000$ \\
Buddhist & 401,000 & $1,082,000$ \\
Unitarian/Universalist & 502,000 & 629,000 \\
Hindu & 227,000 & 766,000 \\
Native American & 47,000 & 103,000 \\
Baha'I & 28,000 & 84,000 \\
Sikh & 13,000 & 57,000 \\
Wiccan & 8,000 & 134,000 \\
\hline
\end{tabular}

\section{WORKERS DESIRE TO HAVE RELIGIOUS EXPRESSIONS AT THE WORKPLACE}

Many discussion topics have been thought to be so potentially divisive that they were avoided in many settings. Religion and politics have been leaders among these topics to avoid, especially when it was thought that they could suddenly change the environment where they were discussed. Coca-Cola initially permitted affinity groups to be formed around a variety of outside interests but not religion or politics, and General Motors does not permit religious affinity groups (Shorto, 2004). However, it appears that Coca-Cola relaxed its restriction on religious affinity groups in 2001 (Hillman, 2004).

In their book introduction to Church on Sunday, Work on Monday Dr. Laura Nash of Harvard and Dr. Scotty McLennan (2001) of Stanford write:

In the past decade, American business has experienced revolutionary changes in how it defines markets, composes institutions, communicates between people, and adapts to changing expectations in society. Not surprisingly, these changes have occasioned an intense quest for new forms of guidance to help business people deal with the marketplace and its impact on people's lives inside and outside the corporations. Perhaps more surprisingly, the quest has led many people to a new interest in spirituality. People of all faiths (and of no faith) consult with spirituality gurus on managing for the twenty-first century. (p. xxi).

Today, more companies than ever are having to deal with religion in their workplaces. For years Christians have often tried to "fly below the radar" with their faith while at work (Hillman, 2004). In recent years ample evidence reveals that workers are unwilling to "check their faith" at the company's door. A Business Week survey revealed " $95 \%$ of Americans say they believe in God or a universal spirit, and 48\% say they talked about their religious faith at work that day [emphasis added], according to the Gallup Organization - it would make sense that, along with their briefcases and laptops, people would start bringing their faith to work" (Conlin, 1999). The San Francisco Chronicle reported that "Secularism no longer is the norm on the job. Seventy percent of respondents to a Personnel Journal magazine survey believe that spirituality has a place at work" (McManis, 1999). In reporting the results of a survey by ACT-1 Group, Janice Bryant Howroyd stated that " 55 percent of working Americans consider spirituality to play a 'very significant' or 'important' role on the job" (NewsUSA, 2003). The survey also pointed out that workers whose household incomes were less than $\$ 25,000$ valued workplace spirituality more highly, as did workers with the highest levels of education (NewsUSA, 2003). Finally, a 2005 NBC News poll stated that 58\% of workers reported that religious beliefs played a role in work decisions, and 65\% said those same beliefs influence their interactions with co-workers (Johnson, 2005).

To understand the personal motivation for this trend, Dr. Nash offers the following explanation:

Spirituality and religions are increasingly finding voice in the workplace for several reasons. Some people are in deep despair...stressed out by the dual demands of work and family life. Others are outraged by their employers' 
willingness to engage in unethical business practices and are seeking a 'higher standard of conduct.' And many people simply want 'more out of life than just a paycheck.' (Hansen, 2002)

People who need or want encouragement and tools for taking their faith into their workplaces also have a growing host of organizations which will assist them. One workplace ministry head said that ten years ago only about twenty-five workplace ministries existed, but the new International Faith and Work Directory currently lists over 1,200 organizations (Hillman, 2004). In fact, one well-known evangelical Christian ministry, the Billy Graham Evangelistic Association (BGEA), initially identified fifty-three different ministry areas which the association might come alongside with their support. They eventually reduced the list to twelve and finally narrowed the most vital to three. Supporting the workplace movement is one of their three areas of focus (Hillman, 2004.)

\section{LEGAL RESOLUTIONS ON EXPRESSION AND ACCOMODATION IN THE WORKPLACE}

Title VII of the Civil Rights Act of 1964 requires an employer, with 15 or more employees, to make "reasonable accommodations" for the religious practices of its employees, unless doing so would cause an undue hardship. However, the Act does not define the meaning of what is reasonable or what an undue hardship is.

For a prima facie case to be established that an employer has failed to reasonably accommodate a request, the $8^{\text {th }}$ Circuit Court stated that the employee must show that the religious belief is bona fide, that it conflicts with an employment requirement, that the employer was informed of the religious belief and/or practice and that the employer disciplined the employee for failing to comply with the conflicting employment requirement. Wilson v. U.W. West Communications (1995). Also, the $9^{\text {th }}$ Circuit Court held that a major requirement is that the religious belief be sincerely held. Heller v. EBB Auto Co. (1993). According to James Oleske (2004) in the Journal of Constitutional Law, the United States Congress has defined religion, in the context of the accommodation requirements of employers, as follows: "all aspects of religious observances and practice, as well as belief, unless an employer demonstrates that he is unable to reasonably accommodate to an employee's religious observance or practice without undue hardship on the conduct of the employer's business" (Oleske, 2004). In addition, in the accommodation process, the Sikh American Legal Defense and Education Fund reports that the employer is "required to make an effort to accommodate an employee's religious practices or beliefs when an employee makes a request" (2004).

Since the passage of Title VII, two major Supreme Court decisions have interpreted the reasonable accommodation provision. The initial case was T.W.A., Inc. v. Hardison (1977), followed in 1986 by Ansonia Board of Education v. Philbrook, (1986). In Hardison, the Court held that an employer was not required to accede to a requested accommodation if the request would require an employer to infringe on the rights of other employees. This principle was reaffirmed by the Supreme Court in U.S. Airways v. Barnett, (2002). In addition, in Philbrook, the Court held that an employer can satisfy its duty under Title VII by offering any reasonable accommodation, even if an alternative accommodation might better protect that employee's interests. In what is probably the most controversial and significant limitation of the reasonable accommodation requirement, the Court held in Hardison and reaffirmed in Philbrook, that "an accommodation causes an 'undue hardship' whenever that accommodation results in 'more than a de minimis' cost to the employer." James Oleske has termed this standard, among other things, a watered-down interpretation of the "undue hardship" standard (Oleske, 2004). In applying this standard, the Hardison Court held that the employer need not accommodate the employee's request when doing so would require the payment of overtime for a voluntary replacement. In other words, the cost for the payment of overtime was more than de minimis. The Hardison Court went further in holding that when a bona fide seniority system exists, the employer is not obligated to make an exception to assist an employee in meeting his religious obligations. Also, Spognardi and Ketay (2000) state in their article entitled "In the Lion's Den: Religious Accommodation and Harassment in the Workplace" (Spognardi and Ketay , 2000) that an accommodation that is inconsistent with a collective bargaining agreement is not required. In Philbrook, the Court dealt specifically with an employee's request for a preferred method of accommodation that does not cause an undue hardship. In its ruling, the Philbrook Court held that the employer is not required to meet any specific accommodation request, but that any reasonable accommodation is sufficient. In meeting its obligation, an employer need only show that it offered, or actually did, reasonably accommodate the employee's request. As a result, employers are not required to accommodate employees in exactly the requested manner. However, the Spognardi and Ketay article in Employee Relations Law Journal reports that the employer 
must make an attempt to accommodate (Spognardi and Ketay, 2000). Attorney Gregory A. Rutchik, in his article entitled "Accommodating Religion in the Workplace," notes examples of reasonable accommodation that include leave without pay, accrued leave, job swaps, and temporary schedule changes (Rutchik, n.d.). Also, Attorney Thomas P. Krukowski reports in an article entitled "Religion in the Workplace: Accommodation and Prevention_of Harassment" published in his monthly newsletter that an Islamic security officer was allowed to wear her hijab in a case settled with the EEOC where it did not impose an undue hardship on the company (Krukowski, 2001). Also, in a case that appears to be somewhat at odds with Philbrook, an employee's suggested accommodation to wear a graphic anti-abortion button, covering it while away from her personal work space, was allowed, even though the employer disagreed and suggested an alternative accommodation (Krukowski, 2001). Religious speech has also been found to be subject to accommodation. In Brown v. Polk County, Iowa (1995) the $8^{\text {th }}$ Circuit Court found that an employee engaging in religious speech was not subject to discipline when the statements made had no provable impact on other employees or the work of the employer. However, Richard T. Alpert, President of Diversity Resources, reports in his article entitled "Religious Diversity in the Workplace" that proselytizing is not protected if it rises to the level of harassment or disruption of the workplace. (Alpert, 2001). The wearing of religious garb also must be accommodated under the undue hardship standard. According to an article entitled "Religious Accommodation in the Workplace," (Institute for Public, n.d.), employees who must maintain a particular physical appearance or manner of dress in keeping with their religion must be accommodated.

As can be seen, accommodation is an area that is often the subject of disagreement. What is termed to be reasonable accommodation is not uniform under the various legislation using this term. For example, the Americans with Disabilities Act of 1990 requires reasonable accommodation of individuals with disabilities (A.D.A. of 1990). Jennings (2003) describes reasonable accommodation as including such things as providing readily accessible facilities, modified work schedules, acquiring or modifying equipment and providing qualified readers or interpreters. The difference under the A.D.A. is that the de minimis cost limitation does not appear to apply. As discussed above, in the area of religious accommodation, almost any cost could be termed to be de minimis. In order to attempt to change the law, a bill entitled the Workplace Religious Freedom Act of 2005 has been introduced in both the House and the Senate to re-define the meaning of reasonable accommodation and undue hardship. In the proposed Senate bill, co-sponsored by Senator Rick Santorum and Senator John Kerry, the term "undue hardship" means an accommodation "requiring significant difficulty or expense." This would represent a different standard than de minimis. Under the proposed bill, areas to be considered in whether an accommodation is an undue hardship requiring significant difficulty or expense include the identifiable cost, including loss of productivity and training, etc., and the financial resources of the employer (Workplace Religious Freedom Act of 2005). Also, general leave days may be used for religious purposes and the failure of the employer to accommodate under the bill will be considered an unlawful employment practice. The proposed act has been introduced in Congress for several years but has yet to pass. Only in the event passage occurs, would religious expression and accommodation in the workplace be greatly expanded.

\section{RELIGIOUS EXPRESSION AND ACCOMODATION FOR FEDERAL EMPLOYEES}

Since the federal government is also a large employer, special focus is needed on religious expression by federal employees. On August 14, 1997, President Bill Clinton issued the "Guidelines on Religious Exercise and Religious Expression in the Federal Workplace," (Guidelines, 1997). This document represents the guiding rules on the issues discussed in this paper, religious expression and accommodation of that religious expression, as they apply to the federal workplace. It should be noted that the guidelines apply to the Federal workplace only and not to state and local government workplaces. The guidelines state that religious expression by federal employees is permitted to the greatest extent possible (emphasis added). Also, federal agencies shall not discriminate against employees based on religion and shall accommodate the free exercise of religion. The guidelines seem to be an attempt of bringing a higher level of protection, at least in the federal workplace, to religious expression.

This had been attempted in an act passed unanimously by the U. S. House and by a 97-3 vote in the Senate and signed by the President in 1993 entitled the Religious Freedom Restoration Act of 1993. That act stated that "Government shall not substantially burden a person's exercise of religion even if the burden results from a rule of general applicability..." with certain exceptions. Also, the act stated that the government could burden the exercise of 
religion only by demonstrating a compelling interest and there was no less restrictive means of regulation available. However, the act was declared unconstitutional by the Supreme Court in Bourne v. Flores (1997) as exceeding the power of Congress in violation of the $14^{\text {th }}$ Amendment and by preferring religion over irreligion.

In the area of expression, the standard in the 1997 federal guidelines state that expression shall not be restricted except where the "employees interest in the expression is outweighed by the government's interest in the efficient provision of public services or where the expression intrudes upon the legitimate rights of others" (Guidelines, 1997) or where the employee's expression could reasonably be interpreted as an "official endorsement of religion" (Guidelines, 1997). Also, the guidelines state that while the government employer may not regulate an employee's religious expression based on content, it may "reasonably regulate the time, place and manner of all employee speech," (Guidelines, 1997) or a so-called content-neutral regulation. Therefore, a ban on all posting of notices, etc. that are not employment related would be allowed, but not a ban on only religious notices. In addition, the guidelines allow employees to engage in religious expression in work areas not open to the public under the same standards. Examples of such expression that are mentioned in the guidelines include keeping a Bible or Koran at a private desk. The guidelines further discuss that employees may express their religion among fellow employees as long as such expression would not be regarded as a government endorsement of religion and that the expression ceases when requested. Examples would be discussions at a coffee break, asking someone to attend church with you, etc. In areas accessible to the public, the guidelines allow expression except when safety concerns or establishment clause issues arise, as the government should not be seen as either inhibiting or endorsing religion. Display of religious jewelry, art and literature would generally be allowed.

Accommodation of religion is another area that the guidelines specifically address. While federal law requires the employer to accommodate the employee's exercise of his or her religion, this accommodation is only required if it would not impose an undue burden on the employer. Also, any burden must be real and not pure speculation. There must be some actual cost to the government or other employees or an actual work disruption in order for the cost to be enough to constitute an undue burden. While this is the general standard, the federal guidelines appear to indicate a slightly different standard, stating that where work rules impose a substantial burden on an employee's exercise of religion, the government must show a compelling interest in denying a work exemption unless there is no less restrictive means available, language mirroring the overturned Religious Freedom Restoration Act. As an example, the guidelines provide that work schedules must be adjusted if an adequate substitute is available, religious garb must be allowed unless it unduly interferes with the safety and function of the workplace, and otherwise empty rooms may be used for prayer time, etc. during lunch, work breaks and other non-working hours.

As can be seen, while the law on religious expression and accommodation in the workplace is somewhat settled, many specific issues are determined on a case-by-case basis. Numerous attempts have been made and are continuing to be made to expand employee religious rights in the workplace. Whether these attempts will be held to be workable and constitutional is yet to be determined.

However, much confusion will remain as both federal and other governmental employers deal with issues of separation of church and state as it is frequently misapplied in employment situations. The comments from a lawyer who successfully defended the religious expression rights of a Honolulu city employee summarize much of the current confusion.

Many supervisors around the U.S. are confused about the alleged separation of Church and State. "The know that it's floating around there," he says, "but if they don't have enough training or specific guidance on how to deal with things, the general default or fallback position is just to say, 'Well, we'd better avoid allowing anyone to do anything religious because we're a public employer.'” But Mattox says that is an incorrect understanding of the law, and prohibiting such religious expression is "not only not required by the Establishment Clause, it's forbidden by the First Amendment and Title 7." (Martin, 2004) 


\section{RELIGIOUS DISCRIMINATION PERCEPTIONS OF WORKERS}

To determine what type of experience employees were having with regard to their religious expression in the workplace, a survey was conducted of evening MBA students at three campuses of Belhaven College in three different metropolitan areas in the southern United States. There were 141 surveys returned with $23 \%$ coming from Orlando, 31\% from Memphis and 46\% from Jackson, Mississippi. As for age of the students, $67 \%$ were 25-39 years old. The racial compositions were $46 \%$ Caucasian, $45 \%$ African-American, $5 \%$ Hispanic and $4 \%$ others. The students were $56 \%$ female and $44 \%$ male. The current employment breakdown was $64 \%$ working with for-profit companies, $19 \%$ for governmental units, and $14 \%$ for other public/private non-profit organizations. When asked about their religion, $89 \%$ had a religious affiliation with the Christian faith with Baptists accounting for the largest group. This reflects the fact that the survey was only distributed to MBA's who chose a Christian college setting, and also reflects that the three campuses surveyed were all in the south where Baptists are more dominant.

The survey first asked the workers if there was a company policy on religious expression at their workplace. Employers had no policy $38 \%$ of the time versus having a policy only $21 \%$ of the time. However, $41 \%$ of the workers were not sure if any policy existed. They were then asked to rate their understanding of this policy on a seven point Likert scale with "1" being understanding the policy "Not at all" and "7" being understanding the policy "Very Well." The mean response was 4.93 showing a more limited understanding of the policy.

The workers were next asked to rate how their own religious expressions had changed over the last ten years on a seven point Likert scale. With "1" signifying "Less Expression" taking place and "7" signifying "More Expression," the mean response was 4.79 showing slightly more personal expression was taking place. They were also asked about the organizational environment. Had the difficulty of showing religious expression changed over the last ten years? On the seven point Likert scale with "1" being "Less Difficult" and "7" being "More Difficult," the mean response was 4.00 revealing that the organizational environment was about the same over the ten year period.

A key part of the survey was measuring how resistance or opposition to religious expression came about and how it was resolved. Therefore, the workers were asked if they had encountered or seen resistance to religious expression at their workplace. The trial survey asked only if they had personally encountered resistance but the initial incidents of resistance were so low the question was broadened to include incidents they had personally observed and not just experienced themselves. With this broader question, still only $21 \%$ of workers, or twenty-nine of the respondents, had encountered or seen resistance/opposition to religious expression in their entire workplace careers. This would tend to confirm the EEOC data quoted earlier showing a low percentage of religious discrimination grievances filed. Knowing what issue caused this resistance or opposition was also important, so workers who had encountered or seen this were asked to choose from a list of possible issues or causes. Table 3 reflects the issues involved and many described multiple issues for the same incidents. Since only twenty-nine workers answered most of the following questions, this shows the need for expanding the sample.

Table 3

Issues Responsible for Resistance or Opposition to Religious Expression in the Workplace

$\begin{aligned} \% & \text { Issue } \\ 41 \% & \text { Religious speech } \\ 24 \% & \text { Appearance expressing religious beliefs (e.g. dress, jewelry) } \\ 24 \% & \text { Personalizing workspace (e.g. posters, quotations, Bible, etc.) } \\ 24 \% & \text { Time off or work break requests for religious observances } \\ 31 \% & \text { Public posting of religious materials or events } \\ 21 \% & \text { Organizing a workplace prayer or study group } \\ 3 \% & \text { Religious activities outside the workplace } \\ 26 \% & \text { Other issues (primarily related to holiday celebration expressions) }\end{aligned}$


There appear to be a variety of issues that create resistance to religious expression in the workplace and often multiple issues can be part of the same incident. However, use of religious speech or conversation appears to be the most frequent trigger of opposition.

It is also helpful to know something about the source of the opposition. Does resistance or opposition usually come from another employee or one's supervisor? Workers revealed that $42 \%$ of the incidents involved just another employee. Another 39\% involved both the employee and supervisor/employer while only $15 \%$ of the opposition came solely from the supervisor/employer.

The research also investigated how the situations were resolved when there was opposition to one's religious expressions. Workers were asked to again choose between a list of possible resolutions. Table 4 below reveals the answers of the workers (29 cases) responding to this question.

Table 4

How Situations Involving Resistance or Opposition to Religious Expression Were Resolved

\begin{aligned} \multicolumn{1}{c}{$\%$} & Resolution \\ $29 \% &$ Situation remains unresolved \\ $13 \% &$ Other employee voluntarily accommodated the religious expressions \\ $4 \% &$ Employer/supervisor voluntarily accommodated the religious expression fully \\ $46 \% &$ No accommodation given so the religious expression was stopped \\ $8 \% &$ Other types of resolution \end{aligned}

These findings suggest that disagreements about religious expression are usually resolved by the expressing party ceasing their activity or by some type of "truce" where the situation is left unresolved. These would account for $75 \%$ of the cases and may also be a reflection of the high percentage (79\%) of workers who have no policy or are not sure if a policy exists.

While the small sample of twenty-nine cases makes it difficult to verify any relationships between responses to different questions, some comparisons suggest possible connections. In using the cross tab function of SPSS, several areas for further study emerged. When the likelihood of encountering resistance to religious expression was compared to several demographic factors, few differences were suggested. Generally equal (and still limited) resistance was found across gender, race, and type of current employer comparisons. With regard to race, both Caucasians and African-Americans showed almost identical resistance by percentage. These two groups represent the $85 \%$ of the workers verifying resistance. The other $15 \%$ were Hispanic and others and did show higher percentages of resistance to their religious expression. Their small sample representation makes this an area for further research.

When likelihood of resistance was compared by location, there were also some differences. For Jackson, Memphis and Orlando the frequencies of resistance were $17 \%, 21 \%$ and $29 \%$ respectively. This may be due to the fact that Orlando is not located in the traditional "Bible belt" encompassing the other two cities but bears further study. With regard to age however, the data did suggest some differences. First, older workers were more likely to have encountered resistance but that likely reflects the fact that they have simply experienced more years as a worker. Second, younger workers (ages 20-29) overwhelmingly (67\%) saw the primary resistance due to another employee only. Older workers (ages 30-49 for the sample MBA students) were far more likely (73\% of the time in fact) to see the employer/supervisor as at least part of the resistance. This bears further research. Is the resistance or opposition primarily do to personality clashes or more authority and systemic issues?

When the likelihood of resistance or opposition was compared with the existence of an organizational policy concerning religious expression, another interesting result was found. Where no policy existed only $15 \%$ had experienced any resistance to their religious expressions. Where workers were not sure if a policy existed, only $16 \%$ had experienced resistance. However, where a policy was known to exist, $43 \%$ claimed to have experienced 
resistance. This substantial difference has at least two possible explanations. First, those who have and understand the organizational policy on religious expression are more likely to recognize resistance. They may understand their rights better and identify unfair resistance more clearly. Another explanation may be that the organization had previous conflict over religious expression so that it developed a policy statement. This is like the chicken or the egg question. Which came first? This bears further investigation.

When the demographic factors are compared to the perceived source of the resistance, some differences do occur. For example, $42 \%$ of the men saw the resistance being between them and another employee only. However, women saw the supervisor being involved, either alone or with another employee, $64 \%$ of the time. When the source of resistance is measured along racial lines, differences are seen also. Caucasians view their problems being limited to only another employee $60 \%$ of the time while African-Americans did so only $30 \%$ of the time. Supervisor involvement is perceived to be part of the resistance much more often by African-American employees. These perceptions of greater supervisory involvement by both women and African-Americans raise a question. When supervisors are involved in resistance to religious expression, the resistance involves authority structures and may be viewed as a systemic problem within the organization. If these cases involved a degree of religious discrimination, then it raises a familiar issue. Is the problem causes by unjust people or unjust systems?

The overall survey will benefit from both further samples among faith-based institutions and samples of MBA's from public universities. The results suggest a relatively low incidence of resistance, at least among Christian workers in the United States. However, the challenges are likely to be felt more strongly among other, less frequently encountered faiths.

\section{CONCLUSION}

Diversity has come to the United States and will only increase in the future. The workplaces will continue to reflect growing cultural diversity and bring with it religious diversity as well. Training workers and especially supervisors to deal with expressions of this religious diversity in a consistent and legal fashion should enhance the workplace as employees do not wish to leave their faith at home but will use it to bring their moral character to the job.

Therefore, companies will benefit from both a policy of religious expression at work along with adequate training for all workers, especially supervisors. There are several elements this training should include. First, many myths exists concerning what is permissible and these must be exposed. The goal should be to teach workers how religious expressions can be rightly handled. The foundation for this is in our constitutional freedom of speech. Free speech during free time should be a given. However, during work time a variety of speech can interrupt the employer's quest for efficiency. All must be treated equally including talk of sports, family, movies, religion, coming holidays, etc. The corporate goal can be reflected in a simple policy on speech in the workplace that includes religious speech.

Second, since several issues may arise regarding accommodation requests for religious expression, the policy statement and training should deal with each of these. Common issues are situations arising from a worker's speech, personalizing workspace, personal time off requests for religious events, posting of religious materials, and personal appearance issues such as religious jewelry or attire. Supervisors should also be challenged to value fairness and objectivity even when they may have strong religious or non-religious convictions of their own.

Third, and finally in most companies, the training should include a discussion of any internal grievance process. Both workers and supervisors can be in error as to their religious rights in the workplace, so any appeal or internal grievance process should be clearly outlined.

For governmental workers and supervisors some additional training will likely be necessary. This training should focus on what "neutrality" toward religion looks like. The myth of "separation of church and state" is so deeply ingrained into the thinking of many that a significant portion of workers and supervisors earnestly believe religion has no place in government buildings. This erroneous belief is increasingly being successfully challenged as 
courts are ruling that governmental employers are overstepping their authority to limit speech. Unraveling this myth which has become so intertwined in the fabric of current governmental operations may pose the greatest training challenge of all.

\section{ACKNOWLEDGEMENTS}

This paper benefited from the contributions of Paul Moyers, J.D. on the legal issues and Terrance McInnis as a research assistant.

\section{REFERENCES}

1. Albert, R. (2001). Religious diversity in the workplace. Diversity Resources, Inc. Retrieved March 29, 2005, from the Diversity Resources, Inc. Web site:

http://users.crocker.com/ amedpub/rc21d/Religion\%20in\%20Workplace11.htm

2. $\quad$ Americans with Disabilities Act of 1990, 42 U.S.C. 12101

3. Ansonia Board of Education v. Philbrook, 479 U.S. 60 (1986)

4. $\quad$ Bourne v. Flores, 521 U.S. 507 (1997)

5. $\quad$ Brown v. Polk County Iowa, 61 F.3d $650\left(8^{\text {th }}\right.$ Cir. 1995)

6. Civil Rights Act of 1964, Title VII, 42 U.S.C. 2000

7. Conlin, M. (1999, November 1). Religion in the workplace. Business Week. Retrieved April 20, 2005, from the Business Week Web site: http://www.businessweek.com/archives/1999/b3653001.arc.htm

8. Gellor, A. (2003, January 20). Expressing religion in the workplace creates tension. The Salt Lake Tribune. Retrieved February 23, 2004, from the Salt Lake Tribune Website: http://www.sltrib.com/2003/Jan/01202003/monday/21843.asp?

9. Gray, H. (2002, March 9). Religion in the workplace. The Kansas City Star. Retrieved February 23, 2004, from The Kansas City Star Web site:

http://www.kansascity.com/mld/kansascitystar/living/religion/2812611.htm

10. Guidelines on Religious Exercise and Religious Expression in the Federal Workplace, 1997

11. Hansen, B. (2002, August 23). Religion in the workplace. CQ Researcher 12(28), 649-672. Retrieved March 29, 2005, from www.cqpress.com

12. Heller v. EBB Auto Co., 8 F3d $1433\left(9^{\text {th }}\right.$ Cir. 1993)

13. Hillman, O. (2004, January/February). The faith at work movement: Opening the 9 to 5 window. Business Review 9, 4-8. Retrieved December 23, 2003, from the Regent University Web site: http://www.regent.edu/acad/schbus/maz/busreview/issue9/faithatwork.html

14. Institute for Public Affairs. (2006). Religious Accommodation in the Workplace. Retrieved January 16, 2006 from the Institute for Public Affairs of the Union of Orthodox Jewish Congregations of America Web site: http://www.ou.org/public/publib/rights.htm

15. Jennings, M. (2003). Business: Its Legal, Ethical and Global Environment ( $6^{\text {th }}$ ed.). Ohio: Thomson.

16. Johnson, A. (2005, March 21). The faith-at-work movement finds a home. MSNBC On- line. Retrieve March 29, 2005, from the MSNBC Web site: http://www.msnbc.msn.com/id/7201269/

17. Kosmin B., Mayer E.and Keysan A. (2001). American Religious Identification Survey 2001. The Graduate Center at the City University of New York. Retrieved April 13, 2005, from the Graduate Center at the City University of New York Web site: http://www.gc.cuny.edu/studies/key findings.htm

18. Krukowski, T. (2001, May). Religion in the Workplace: Accommodation and Prevention Of Harassment. FMI Labor Information Service Newsletter, 9(4). Retrieved January 16, 2006 from Web site: www.fmi.org/newsletters/uploads/LaborInfoService/FMImay01.PDF

19. McManis, S. (1999, October 22). When cultures class on the job companies struggle to accommodate workers of different religious faiths without alienating other. San Francisco Chronicle. Retrieved January 21, 2004, from the SFGate Web site: http://www.sfgate.com/article.cgi?file=/chronicle/archive/1999/10/22/BU40164.DTL

20. Martin, A. (2004, May 13). Honolulu employee's free-speech suit prompts city policy change. Agape Press News Service. Retrieved May 14, 2004 from the Agape Press Web site: http://headlines.agapepress.org/archive/5/132004c.asp 
21. Nash L. and McLennan, S. (2001). Church on Sunday, work on Monday: the challenge of fusing Christian values and business life. San Francisco: Jossey-Bass.

22. NewsUSA. (2003). Spirituality in the workplace 'significant' survey finds. NewsUSA. Retrieved March 29, 2005, from the NewsUSA Web site: http://healthyliving.preferredconsumer.com/work/workplace_spirituality.html

23. Oleske, J. (2004, March). Federalism, Free Exercise, and Title VII: Reconsidering Reasonable Accommodation. Journal of Constitutional Law. 6(3), 525-537. Retrieved January 13, 2006.

24. Pew Forum on Religion and Public Life Conference. (2002, May 21). Reconciling Obligations: Accommodating Religious Practice on the Job. Retrieved October 31,2005, from the Pew Forum on Religion and Public Life Web site: http://perforum.org/events/print.php?EventID=27

25. Religious Freedom Restoration Act of 1993, H.R. 1308

26. Rutchik, G. (n.d.). Accommodating Religion in the Workplace. Retrieved January 16, 2006 from Web site: www.ccc.mcle.com/tests/ss6009a.pdf

27. Sampson, D. A. (2004). A world of opportunity: the case for optimism in the worldwide economy. Economic Development America, Fall 2004, 3-8. Economic Development Information Coalition. Retrieved December 2, 2005, from the Economic Development Administration Web site: http://www.eda.gov/NewsEvents/Edevinfocoalition.xml

28. Shorto, R. (2004, October 31). Faith at work. The New York Times. Retrieved November 5, 2004, from The New York Times Web site: http://www.nytimes.com/2004/10/31/magazine/31FAITH.html

29. Sikh American Legal Defense and Education Fund (SALDEF). (2004). An Employer's Guide to Religious Accommodation. Retrieved March 13, 2006, from the Sikh American Legal Defense and Education Fund Web site: http://www.saldef.org/default.aspx?zone=article.view\&a995

30. Spognardi, M. and Ketay, S. (2000). In the Lion's Den: Religious Accommodation and Harassment in the Workplace. Employee Relations Law Journal, 25(4), 7-27. Retrieved January 13, 2006.

31. T.W.A., Inc. v. Hardison, 432 U.S. 63 (1997)

32. Tanenbaum Center for Interreligious Understanding. (1999). Religious bias in the workplace: the Tanenbaum center's 1999 survey of employees-Executive Summary. New York, NY: Author. Retrieved April 19, 2005, from the Tanenbaum Center for Interreligious Understanding Web site: http://www.tanenbaum.org/programs/diversity/survey1.aspx

33. Tanenbaum Center for Interreligious Understanding. (2001). Religion in the workplace: the Tanenbaum center and society of human resource management 2001 survey of HR professionals. New York, NY: Author. Retrieved April 19, 2005, from the Tanenbaum Center for Interreligious Understanding Web site: http://www.tanenbaum.org/programs/diversity/survey/2.aspx

34. U.S. Airways v. Barnett, 535 U.S. 391 (2002)

35. Wilson v. U.S. West Communications, 58 F.3d 1337 ( $8^{\text {th }}$ Cir. 1995)

36. Wolverton, M. (1998, November-December). Christians At Work. The Plain Truth. Retrieved July 31, 2003, from the Plain Truth Ministries Web site: http://www.ptm.org/98PT/NovDec/ChristiansAtWork.htm

37. Workplace Religious Freedom Act of 2005, S 677 IS 


\section{NOTES}

